Lana Tomčić ${ }^{1}$

Univerzitet u Novom Sadu, Filozofski fakultet
UDC: $37.018 .26: 371.212 .72$

doi: $10.19090 /$ ps.2019.1.54-68

Primljen: 22.1.2019.

Prihvaćen: 19.6.2019.

PREGLEDNI NAUČNI RAD

\title{
PREVENCIJA ŠKOLSKOG NEUSPEHA: ZNAČAJ PORODICE
}

\author{
Apstrakt
}

U pedagoškoj literaturi školski neuspeh se najčešće definiše kao neispunjavanje minimuma zahteva u sticanju znanja i ostvarivanju vaspitno-obrazovnih zadataka tokom nastavnog procesa. Porodica, kao osnovno socijalno okruženje u kome dete stiče prva iskustva, prve modele i uzore, prepoznaje se kao jedan od najznačajnijih faktora školskog neuspeha učenika. Istraživački cilj ovog rada predstavlja pregled faktora porodične sredine koji utiču na pojavu školskog neuspeha, kao i značaja, odnosno mogućnosti uspostavljanja partnerstva porodice i škole u cilju prevencije školskog neuspeha. Istraživački cilj se ostvaruje na teorijskom nivou, uz primenu metode teorijske analize. Na osnovu proučavanja relevantne literature izvodi se zaključak da su sledeći faktori prepoznati kao dominantni: socioekonomski status, struktura porodice, vaspitni stil roditelja, njihova uključenost u obrazovanje dece, očekivanja i emocionalna podrška. Svesni činjenice da savremeni način života stavlja roditelje pred raznovrsne izazove i otežava ostvarenje njihove uloge, istraživači školskog neuspeha su ispitivali mogućnosti uspostavljanja partnerstva porodice i škole u cilju prevladavanja školskog neuspeha, te su u radu, između ostalog, predstavljene i dve strategije partnerstva: koncept roditeljske uključenosti i savetodavne strategije.

Ključne reči: porodica, školski neuspeh, faktori neuspeha, partnerstvo porodice $i$ škole.

\section{Uvod}

Porodica, kao osnovno socijalno okruženje u kome dete stiče prva iskustva, prve modele i uzore, prepoznaje se kao jedan od najznačajnijih faktora školskog neu-

\footnotetext{
${ }^{1}$ Rad je nastao u okviru projekta „Kvalitet obrazovnog sistema Srbije u evropskoj perspektivi“ (KOSSEP), br. 179010, čiju realizaciju finansira Ministarstvo prosvete, nauke i tehnološkog razvoja Republike Srbije.

Student doktorskih studija, e-mail: lana.tomcic@gmail.com
} 
speha učenika. Njeno dejstvo je nekada jače od dejstva drugih, celishodnije organizovanih činilaca vaspitanja (Trnavac, 2010). U relevantnoj pedagoškoj literaturi školski neuspeh se definiše kao posledica poremećaja koji se odnose na opadanje postignuća u učenju i pada određenog nivoa znanja, prouzrokovan intelektualnom sposobnošću, razvojem učenika i sredinskim faktorima (Đorđević, 1989). Kao neuspešni su identifikovani oni učenici koji ,pokazuju ozbiljno odstupanje između očekivanog (mereno standardnim rezultatima testa uspeha ili procenama kognitivnih ili intelektualnih sposobnosti) i stvarnog postignuća (mereno školskim ocenama i procenama nastavnika)“ (Reis \& McCoach, 2000: 157).

Stanojlović (2016) faktore školskog neuspeha grupiše na sledeći način: a) društveno-ekonomski faktori - razvijenost i karakteristike društvene sredine, te uslovi porodične sredine (socioekonomski status porodice, struktura porodice, ponašanje roditelja prema deci i odnosi među članovima porodice); b) somatsko-psihološki faktori - zdravstveno-fizičko stanje, opšte i posebne sposobnosti i osobine ličnosti, aktivnost i ponašanje učenika u vaspitno-obrazovnom procesu, kao i u slobodnom vremenu; c) školski faktori - prostorni, nastavno-tehnički i kadrovski uslovi rada u školi, opšta psiho-socijalna klima u školi, osobine nastavnika i poznavanje individualnih razlika među učenicima i njihovih porodičnih uslova, sistem praćenja i vrednovanja razvoja i postignuća učenika u školskom učenju, kao i prilagođenost nastavnog plana i programa, udžbenika uzrasnim karakteristikama učenika. Sličnu, gotovo istu, klasifikaciju faktora školskog neuspeha dali su i drugi autori (Babarović, Burušić i Šakić, 2009; Gutvajn i Ševkušić, 2013; Rečić, 2003, Zloković, 1998; Šaranović-Božanović, 1984).

Santin ističe da je "proizvodnja obrazovanja u detetu vrlo složen proces u kojem se različite varijable $i$ agensi međusobno povezuju, ali gde je porodica pravi kamen temeljac za izbegavanje školskog neuspeha" (Santín, 2006: 199). Zbog toga je važno da se otkriju i prouče faktori porodične sredine koji kroz razvoj deteta, još od najranijeg uzrasta, utiču na formiranje njegovih radnih navika, njegovog odnosa i stava prema školi i školskim obavezama, jer ukoliko se ne postupa na adekvatan način sa detetom na vreme, to može da ostavi posledice na njegovo akademsko postignuće, dovodeći do razvoja školskog neuspeha.

\section{Povezanost porodice, školskog neuspeha učenika i škole: teorijsko polazište}

Teorijski okvir koji daje osnovu za povezivanje porodice i škole, kao sredinskih faktora, i školskog postignuća, odnosno školskog neuspeha učenika nalazi se u Bronfenbrenerovoj ekološkoj sistemskoj teoriji razvoja. Ekosistem (okolina), na dete utiče transakcijskim putem kroz četiri različita nivoa sistema (Slika 1): mikrosistem (neposredni kontakt detetovog života i razvoja koji obuhvata porodicu, školu/odeljenje i neposredno lokalno okruženje - lokalnu zajednicu, crkvu, igralište), mezosistem (obuhvata odnose između delova mikrosistema: porodice, odnosno roditelja i škole kao 
institucije), egzosistem (podrazumeva širi kontekst od mikrosistema i mezosistema obuhvatajući skup sredina u kojima dete ne učestvuje direktno, ali koje se odražavaju indirektno na njegov život: osobenost radnog mesta roditelja, lokalna vlast, školsko veće), i makrosistem (obuhvata sve ostale sistemske komponente kroz vrednosti, ideologiju, zakone i kulturna obeležja date društvene zajednice, te kao takav sadrži različite sisteme verovanja, resursa, stilova života i obrazaca društvene razmene) (Vasta, Haith i Miller, 2005, prema: Eret, 2012; Polovina, 2009; Zuković, 2012). Ovi sistemi su međusobno povezani hronosistemom, koji podrazumeva uticaj promena i stalnosti na razvoj osobe u okolini, kroz duži vremenski period (Wagner \& Jakab, 2008, prema: Krstić, 2016).

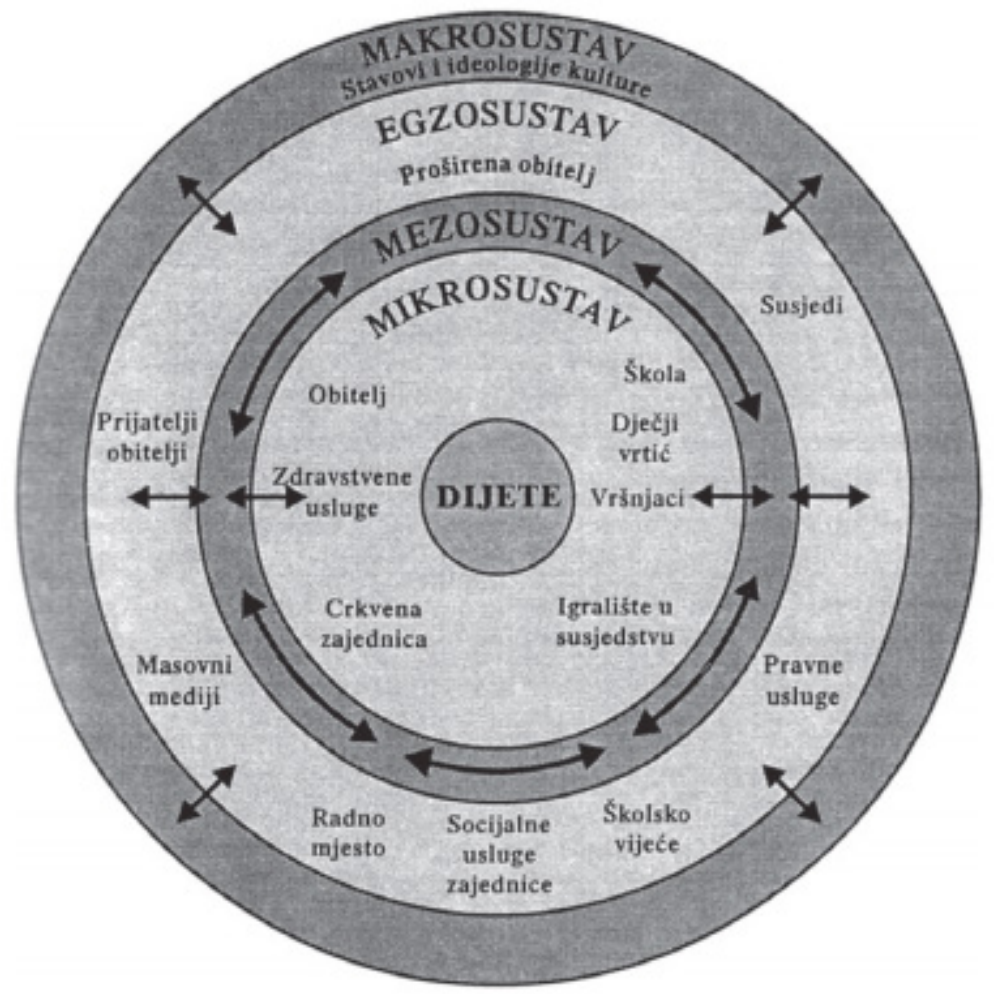

Slika 1. Bronfenbrenerov ekološki model okoline (Vasta, Haith i Miller, 2005:61, prema: Eret, 2012:145)

Primenljivost ovog modela na proučavanje školskog neuspeha je široka: od odnosa između karakteristika porodice i školskog funkcionisanja deteta, preko saradnje porodice i škole, do uticaja proksimalnih procesa (neposredne interakcije, uključenosti 
i angažovanost u odnosu dete-roditelj, dete-nastavnik, dete-vršnjaci u razredu i lokalnom okruženju) na distalne obrazovne ishode kao što su školske ocene, obrazovne aspiracije i preferencije (Nelson \& Keith, 1990; Polovina, 2007; Benner, Graham \& Mistry, 2008, prema: Polovina, 2009). U porodici, njenom funkcionisanju, uslovima porodičnog života i ponašanju roditelja, nalaze se objašnjenja za kasnije ponašanje deteta u životu, za njegove psihičke probleme i socijalne nesporazume, ali i neuspehe, kako životne tako i akademske (Trnavac, 2010). Porodica i škola predstavljaju primarni i međusobno isprepletani mikrosistem u kojima se odvija detetov život i razvoj, te se kroz saradnju roditelja i škole, odnosno nastavnika, može afirmisati društvena podrška porodici i porodičnim procesima (Ahuja, 2008, prema: Polovina, 2008).

\section{Porodične determinante školskog neuspeha}

Brojna istraživanja su pokazala da socioekonomski status, struktura porodice, vaspitni stil roditelja, njihova uključenost u obrazovanje dece, očekivanja i emocionalna podrška, predstavljaju faktore porodične sredine koji doprinose pojavi školskog neuspeha učenika (Gutvajn i Ševkušić, 2013; Malinić, 2009; Önder, 2016; Rečić, 2003; Stanojlović, 2016; Zloković, 1998; Šaranović-Božanović, 1984).

Socioekonomski status porodice ogleda se u ekonomskom položaju članova porodice u socijalnom sistemu. Kao najznačajnije indikatore socioekonomskog statusa Malinić (2009) navodi: obrazovni nivo, zanimanje, zaposlenost i porodične prihode. Rezultati brojnih istraživanja pokazuju da nizak socioekonomski status korelira sa suženim mogućnostima izbora škola, odnosno obrazovnim nejednakostima, školskim neuspehom, posebno sa lošim obrazovnim rezultatima iz prirodnih nauka (fizike, hemije, matematike), visokim rizikom od ranog napuštanja školovanja, nižim samopouzdanjem i višim nivoom školske anksioznosti koji vode ka nižem obrazovnom postignuću, nižim intelektualnim sposobnostima, slabije razvijenim akademskim i socijalnim veštinama (Baucal i Pavlović-Babić, 2009; Baucal, 2012; Burstein, Fischer \& Miller, 1980; Gregurović i Kuti, 2010; Lam, 2014; Matković, 2010; Pavić i Vukelić, 2009; Yildirim \& Eryilmaz, 1999; Young \& Fraser, 1993; Zloković, 1998). Obrazovanje roditelja je značajno jer pokazuje koliko su roditelji osposobljeni da pruže pomoć učeniku u određenim školskim zadacima, kakvu vrednost pridaju obrazovanju, razvoju akademskih ciljeva, te na taj način deca generišu i imitiraju njihovo ponašanje (Álvarez-Blanco \& Martínez-González, 2016). Istraživanje autora Hamre i Pianta (Hamre \& Pianta, 2005) ukazuje na dve centralne kategorije rizika dece za rani školski neuspeh: demografske i funkcionalne rizike. Pre ulaska u školu, u velikoj meri su porodični i demografski faktori ti koji deci ugrožavaju uspeh. Jedan od najpouzdanijih i najčešćih pokazatelja demografskih rizika je nizak nivo obrazovanja majki. Jedan od razloga za to jeste taj što deca majki sa niskim nivoom obrazovanja imaju manje šanse da budu izložena čestom i bogatom jeziku i pismenosti, te polaze u školu sa manje razvijenim akademskim veštinama. Takođe, rezultati istraživanja koje je sprovela autorka Onder (Önder, 2016) dovelo je do zaključka 
da na školski neuspeh, kada su u pitanju porodični faktori, u najvećoj meri utiču: nizak socioekonomski status porodice, nizak obrazovni nivo roditelja, struktura porodice i nedostatak podrške za akademsko angažovanje učenika.

Struktura porodice, disfunkcionalni porodični odnosi, kao i konflikti među roditeljima dovode do poteškoća u intelektualnom, emocionalnom i moralnom razvoju deteta, što može dati za krajnji rezultat neuspeh u školskom učenju. Naime, dečaci koji ne žive sa očevima ostvaruju slabiji uspeh u školi, u odnosu na devojčice iz nepotpunih i dečake iz potpunih porodica. Takođe, u nepotpunim porodicama je zapažen veći procenat dece sa nezadovoljavajućim školskim uspehom, u poređenju sa decom iz potpunih porodica. Međutim, taj procenat je manji u odnosu na decu iz potpunih porodica, ali u kojima se manifestuju česti ili svakodnevni konflikti među roditeljima (Malinić, 2009). U ovakvim uslovima dete nema dovoljno podsticaja i pomoći od strane roditelja, nema pozitivnog uzora u ponašanju, uskraćeno je u osećaju sigurnosti i ljubavi (Janković i Prošić-Santovac, 2009). U strukturi porodice značajnu ulogu u školskoj uspešnosti ima i broj dece u porodici. Rezultati istraživanja su pokazali da najveći broj izrazito neuspešnih učenika, u osnovnoj i srednjoj školi, zapravo potiče iz mnogočlanih porodica (Malinić, 2009).

Vaspitni stil roditelja predstavlja „tipične emocionalne prilike roditeljstva unutar kojih se ostvaruju odnosi između deteta i roditelja“ (Čudina-Obradović i Obradović, 2006:243). U savremenoj pedagoškoj literaturi su identifikovana tri primarna modela roditeljskih stilova u vaspitanju: demokratski, autoritaran i permisivan. Rezultati istraživanja Lacković-Grgin (Lacković-Grgin, 1982, prema: Malinić, 2009), ukazuju na to da učenici koji potiču iz porodica u kojima su dominantno zastupljeni autoritarni ili permisivni stilovi postižu znatno slabije rezultate u školi, u poređenju sa učenicima iz porodica u kojima vlada demokratski stil, što je u saglasnosti sa rezultatima istraživanja autorke Pelemiš (2017). U demokratskim porodicama vlada tolerancija, razumevanje, osećaj sigurnosti, što umnogome doprinosi da se učenici uspešnije suoče sa obrazovnim zadacima i zahtevima koje pred njih postavlja škola (Zloković, 1998). U prevazilaženju ili sprečavanju školskog neuspeha, emocionalna podrška koju pružaju roditelji je od izuzetnog značaja jer roditelji na taj način šalju svom detetu poruku da veruju u njega, u njegove sposobnosti i kompetencije. Ukoliko podrška, motivacija i podsticaji od strane roditelja izostanu to može da ima za posledicu nisko samopouzdanje kod deteta i pojavu školskog neuspeha (Škutor, 2014).

Uključenost roditelja u obrazovanje dece zavisi od vrste vaspitnog stila koji određuje odnos roditelja prema detetu. Istraživanja su pokazala da su roditelji učenika koji ostvaruju izrazito slab uspeh u školi u niskom stepenu uključeni u školske aktivnosti svoje dece, odnosno da se povećanjem stepena uključenosti roditelja u obrazovanje deteta postiže i bolje školsko postignuće (Bedeniković, 2009; Klemenović i Cvijanović, 2017; Pahić, Miljević-Riđički i Vizek-Vidović, 2010; Sremić i Rijevac, 2010; Sušanj-Gregorović, 2017; Vrkić-Dimić, Zuckerman i Blaži-Pestić, 2017). Treba napraviti razliku u pogledu vrste uključenosti roditelja u školske aktivosti. Može se go- 
voriti o uključenosti na osnovu inicijative samih roditelja, ili o uključenosti na osnovu inicijative škole. Za školski uspeh učenika daleko se efikasnije pokazala uključenost inicirana od strane roditelja (Malinić, 2009). S tim u vezi, predlažu se raznovrsne forme uključivanja roditelja u obrazovanje svoje dece, odnosno u život škole, kao što su: angažovanost roditelja u aktivnostima odeljenskih i školskih organizacija, praćenje rada i rezultata učenika, uključivanje u timsko rešavanje školskih problema, organizovanje zajedničkih akcija i sl. Kao rezultat ovakve uključenosti roditelja u obrazovanje dece javlja se bolje školsko postignuće učenika (Milošević, 2002).

Konačno, kao veoma značajan faktor porodične sredine koji utiče na školsko postignuće učenika, pa samim tim i na mogućnost javljanja školskog neupeha, jesu očekivanja roditelja. Istraživanja su pokazala da roditelji koji imaju visoka očekivanja postavljaju više standarde, zahteve i daju više podsticaja svojoj deci, već od ranog uzrasta, što kasnije dovodi do viših akademskih postignuća učenika (Broocock, 1972, prema: Slijepčević, Zuković i Kopunović, 2017). Mnogobrojna istraživanja iz ove oblasti su utvrdila da roditeljske aspiracije i očekivanja predstavljaju faktor rizika učenikovog školskog postignuća i njegovog verovanja u sopstvene snage (Jacob, 2010, prema: Slijepčević i sar., 2017). Ispitujući koliko aspiracije roditelja sa jedne strane „guše“, a sa druge podstiču školski uspeh učenika, autori Suzić i Tunjić (Suzić i Tunjić, 2001, prema: Slijepčević i sar., 2017) su uvideli da učenici doživljavaju roditeljska očekivanja kao jedan od vidova kontrole, njih i njihove budućnosti. Pojedini roditelji, neprihvatajući sve veću samostalnost svoje dece, nastoje da povrate i održe kontrolu nad decom upravo visokim očekivanjima. Sa druge strane, kako bi izbegla kazne i konflikte sa roditeljima, deca se vode previsokim očekivanjima roditelja, što nažalost, često može da dovede do smanjenja motivacije, sputavanja u izražavanju i iskazivanju sposobnosti. Suprotno ovim roditeljima se nalaze roditelji sa preniskim očekivanjima, što je često posledica vrednovanja putem vlastitih psiholoških manjkavosti, a ne detetovih. Prethodno navedeno nas navodi na zaključak da roditelji moraju biti svesni mogućnosti svoje dece, te u skladu sa njima uspostaviti i sopstvena očekivanja, kako bi na pravilan način podsticali njihov razvoj i akademska postignuća.

\section{Partnerstvo porodice i škole u cilju prevladavanja školskog neuspeha}

Kada je u pitanju školski neuspeh učenika, treba uzeti u obzir da loše školsko postignuće ne znači istovremeno i nedostatak intelektualnih sposobnosti učenika, već da se često javlja kao posledica neadekvatne podrške okoline. U brojnim istraživačkim nalazima i evaluaciono-istraživačkim procenama (Epstein \& Jansorn, 2004; Redding et al., 2004; Guskey et al., 2006; Waden \& Westat, 2006, prema: Polovina, 2008) utvrđena je korelacija između različitih oblika roditeljskog povezivanja sa školama, odnosno nastavnicima (roditeljski sastanci, individualni razgovori sa nastavnicima, volontiranja u školi) i školskog postignuća, urednog pohađanja škole i razvijenosti obrazovnih aspiracija učenika. 
Istovremeno, važna je otvorenost porodice prema drugim mikrosredinama, imajući u vidu polazište Bronfenbrenerove ekološke teorije, svaki od sistema posredno ili neposredno utiče na funkcionalnost porodice. U vezi sa tim, upravo bi vaspitno-obrazovne institucije, kao „eko-niše“ u kojima deca provode dosta vremena, mogle biti važan resurs i osnovni sistem u osnaživanju porodice i prevažilaženju problema (Krstić, 2016). Tako, Bronfenbrener ističe četiri vrste povezanosti između porodice i škole, koje se mogu primeniti i na oblast školskog neuspeha: a) učešće u više okruženja - nastaje kada se jedna osoba uključi u aktivnosti u više od jednog okruženja, odnosno kada dete provodi vreme i kod kuće i u školi; b) indirektne veze - kada ista osoba ne učestvuje aktivno u oba okruženja veza među njima može biti uspostavljena posredstvom treće osobe, odnosno veza između roditelja i nastavnika može biti uspostavljena posredstvom deteta; c) komunikacija između okruženja - kada se poruke prenose iz jednog u drugo okruženje sa otvorenim namerama da se osobama u drugom okruženju pruže specifične informacije, na primer roditeljski sastanci; d) znanje o drugom okruženju - informacije i/ili iskustvo koje postoje u jedom okruženju a tiču se drugog, kao što je na primer situacija kada roditelj obaveštava nastavnika o specifičnom događaju koji se desio u učionici (Bronfenbrenner, 1979, prema: Milošević, 2002).

Partnerstvo porodice i škole u cilju prevencije i prevladavanja školskog neuspeha podrazumeva recipročnu interakciju nastavnika i roditelja, kao i usklađivanje aktivnosti, izgradnju pozitivnih stavova u oba smera, obezbeđivanje komplementarnosti uloga, ali i racionalnu raspodelu uticaja, tako da roditelj i nastavnik imaju kontrolu nad svojim domenom aktivnosti (Milošević, 2002). U tom smislu, posebno se ističe važnost interakcije koja se ostvaruje između porodice i škole, kao vaspitno-obrazovnim resursom i sistemskim okruženjem u kome dete provodi najviše vremena u periodu intenzivnog rasta i razvoja (Popović i Zuković, 2014). Aktivno učešće roditelja u školovanju svoje dece "pozitivno utiče na akademske performanse, socijalne veštine, samopoštovanje, akademske i radne navike, pozitivne stavove prema školi" (Musitu \& Cava, 2001: 133).

\section{Koncept roditeljske uključenosti}

Saradnja porodice i škole u prevenciji školskog neuspeha podrazumeva recipročnu interakciju roditelja i nastavnika, usklađivanje aktivnosti, pozitivna očekivanja i komplementarnost uloga (Zuković, 2013). Koncept roditeljske uključenosti podrazumeva aktivno i efikasno uključivanje roditelja u život i rad škole kroz sledećih šest tipova roditeljskog uključivanja:

1) Roditeljstvo - podrazumeva pružanje pomoći porodicama predstavljanjem adekvatnih veština roditeljstva, razvijanjem razumevanja procesa razvoja dece i adolescenata, kao i uspostavljanjem podsticajne porodične sredine za razvoj deteta, odnosno za podršku procesu učenja primerenom uzrastu učenika. 
2) Komunikacija - obuhvata kreiranje dvosmernih kanala komunikacije između škole i porodice u cilju upoznavanja sa školskim programima i mogućim načinima napredovanja učenika.

3) Volontiranje - škola treba da bude inicijator saradnje sa roditeljima kroz adekvatne aktivnosti i radionice u kojima bi roditelji bili angažovani kao volonteri i na taj način pružili podršku učeniku u vaspitno-obrazovnom procesu.

4) Učenje kod kuće - podrazumeva uključivanje roditelja u akademsko učenje svoje dece kroz domaće zadatke i aktivnosti vezane za nastavni program, kao i podsticanje nastavnika da kreiraju zanimljive zadatke o kojima bi učenici diskutovali sa roditeljima.

5) Odlučivanje - osnažiti roditelje kao učesnike i lidere u školskim timovima i odborima u donošenju odluka vezanih za život i rad škole.

6) Saradnja sa zajednicom - podrazumeva identifikovanje i implementaciju resursa lokalne zajednice koji bi doprineli razvoju i jačanju škole, porodice $\mathrm{i}$ učenika (Epstein \& Salinas, 2004).

Autori Li i Boven ističu da se roditelji mogu uključiti u obrazovanje svoje dece kako u kućnim tako i u školskim uslovima. U kućnim uslovima roditelji se uključuju pružajući im pomoć u domaćim zadacima, zatim, razgovorom o školskom radu i školskim iskustvima, kao i pružanjem pomoći u strukturisanju kućnih aktivnosti, dok u školskim uslovima mogu pružiti pomoć organizujući i učestvujući na konferencijama zajedno sa nastavnicima, volontiranjem u školskim akcijama i aktivnostima, kao i uključivanjem u sponzorisane aktivnosti u školskoj organizaciji (Lee \& Bowen, 2006). Volontiranja u školskom okruženju se čestu ohrabruju, ali nivoi angažovanja roditelja najčešće obuhvataju poslove administratora. Veoma retko roditelji, čak i oni koji poseduju stručna znanja o podučavanju i učenju, dobiju mogućnost da predlože mere ili strategije za unapređenje nastavnog rada sa neuspešnim učenicima. Najprihvatljiviji vid pružanja akademske pomoći bi bio individualni ili grupni rad sa učenicima koji imaju problem u učenju (Howard \& Reynolds, 2008).

Roditelji treba da, pre svega, nastavniku pokažu interesovanje za uključivanje u školske aktivnosti u cilju pružanja pomoći svom detetu da prevaziđe školski neuspeh. Socijalni kapital i društvena kontrola su dva glavna mehanizma pomoću kojih uključenost roditelja promoviše uspeh. Prvi, socijalni kapital se sastoji od veština koje učeniku pružaju mogućnost da napreduje među vršnjacima, kao i da grupne zadatke rešava sa što manjim brojem konflikata. Porast socijalnog kapitala znači da uključenost roditelja u školske aktivnosti dece doprinosi povećanju roditeljskih veština i njihovoj informisanosti, što ih sveukupno čini bolje pripremljenim za pružanje pomoći deci u školskim obavezama. Uz socijalni kapital, spominje se i kulturni, koji se odnosi na nivo i prirodu direktne uključenosti roditelja u obrazovni proces. Zapravo, kulturni kapital se definiše kao set veština i mogućnosti, lingvističkih i kognitivnih, uz detaljnije poznavanje kulturnih normi i formi izražavanja. Kulturni i socijalni kapital su 
povezani sa emocionalnim, koji predstavlja unutrašnji resurs i elastičnost koja detetu omogućava da podnese stres i da mu se odupre. Drugi spomenuti mehanizam jeste društvena kontrola, koja se javlja u situacijama kada se porodica i škola udruže kako bi postigli dogovor oko adekvatnog ponašanja učenika, kako kod kuće tako i u školi. Zapravo, kada učenici dobijaju slične poruke o ponašanju iz različitih izvora, poruka je jasna, sa što manje konfuzija u vezi sa očekivanjima. Bez obzira za koji se mehanizam roditelji opredele, učenici dobijaju pozitivnu poruku o važnosti obrazovanja koja razvija učeničke kompetencije, motivaciju za učenjem, a kao krajnji rezultat se javlja bolje postignuće učenika u školi (Malinić, 2009).

Zajedničkim snagama porodica i škola deluju, kako preventivno tako i korektivno. Zato je potrebna stalna informativna veza između ovih činilaca kako bi se na taj način ostvarilo jedinstvo vaspitnog delovanja, što direktno preventivno deluje po pitanju javljanja školskog neuspeha. Praksa pokazuje da se saradnja između porodice i škole najčešće ostvaruje posredstvom roditeljskih sastanaka i individualnih razgovora, a za efikasnije ostvarivanje cilja saradnje neophodno je iskoristiti i druge mogućnosti, kao što su: predavanja za roditelje, aktivnosti u kojima učestvuju nastavnici, roditelji i deca, zajedničko planiranje i organizovanje određenih aktivnosti i događaja, pismena komunikacija između porodice i škole, odnosno roditelja i učitelja/nastavnika, posete porodici, i slične mogućnosti (Popović, 2010).

\section{Savetovanje kao vid prevencije školskog neuspeha}

Suštinu savetodavnog rada u školi predstavlja pružanje kako posredne tako i neposredne pomoći i podrške učenicima u njihovom rastu, razvoju kao i školskom napredovanju (Zuković, 2017). Model na kojem počiva savetovanje kao vid prevencije školskog neuspeha napravile su autori Blauer i Valc (Bleuer \& Walz, 2002). Zapravo reč je o modelu koji počinje upoznavanjem školskog savetnika sa ulaznim (,input“) varijablama, organizovanim u tri seta. Prvi set obuhvata spoljašnje varijable koje čine porodica, vršnjaci, zajednica, škola i nastavnici, metode učenja i težina zadatka. Sledeći se odnosi na kognitivne varijable, koje se fokusiraju na mentalne sposobnosti i stavove učenika, njihovo predznanje i prethodno iskustvo učenja, veštine i stilove učenja. Treći set obuhvata afektivne varijable kao što su dispozicije, raspoloženje, psihološki razvoj, vrednosti i ciljevi, otpornost. Ulazne varijable i učenikove životne i karijerne aspiracije nastavljaju interakciju vodeći učenika ka percepciji sopstvenih akademskih sposobnosti i želje za postignućem, odnosno od „Ja mogu da uspem“ do „Ja želim da uspem“. Učenik treba da nastavi kroz fazu opredeljenja i posvećenosti „Ja ću uspeti“, nakon čega ulaže napor u ostvarenje svojih ciljeva. Zalaganje rezultira u oceni, a ocene su srazmerne uloženom zalaganju i trudu.

U radu sa neuspešnim učenicima, autori ovog modela preporučuju savetnicima sledeće korake kako bi njihov rad sa učenicima bio što kvalitetniji i efikasniji: 
$>$ uz kombinaciju indvidualnog, grupnog i/ili porodičnog savetovanja, kao i uz konsultaciju sa nastavnicima, savetnici treba da istraže stepen u kojem svaka „,input" varijabla, iz ovog modela, predstavlja prednost ili barijeru za učeničko postignuće,

$>$ savetnici treba zajedno sa učenicima da naprave listu varijabli i da svaku varijablu ocene na skali od 1 do 5 , pri čemu 1 predstavlja postojeće barijere, a 5 postojeće prednosti,

> treći korak podrazumeva da savetnici zajedno sa učenicima, za svako „1“ pronađu načine prevazilaženja prepreka, a za svako ,5“ načine koji omogućavaju učenicima dalje osnaživanje sopstvenih prednosti,

$>$ potrebno je staviti akcenat na jednu prepreku i jednu prednost istovremeno, pripremiti akcioni plan koji podrazumeva specifične aktivnosti, za koje se učenici obavezuju da će ih u predviđenom vremenu izvršiti, zatim ogranizovati sastanak sa savetnikom u cilju preispitivanja učenikovog napredovanja,

$>$ kao poslednji korak navodi se nastavak fokusiranja na ostale prepreke i prednosti uz odgovorajući podsticaj za postignuti nivo uspeha učenika (Bleuer \& Walz, 2002).

\section{Zaključak}

Školski neuspeh je problem za čije rešenje ne postoji univerzalna strategija ili model. Iz tog razloga, bilo je neophodno proučiti faktore koji dovode do njegovog javljanja, jer ono što za jednog učenika predstavlja barijeru, odnosno faktor rizika, za drugog je prednost, kamen temaljac rešenja problema. Porodica, kao osnovno socijalno okruženje u kome dete stiče prva iskustva, predstavlja jedan od najčešćih uzročnika školskog neuspeha. Socioekonomski status, struktura porodice, vaspitni stilovi roditelja, uključenost u obrazovanje dece, kao i očekivanja roditelja, predstavljaju deo širokog dijapazona mogućih faktora rizika proizašlih iz porodične sredine.

Proučavajući relevantnu literaturu i rezultate dosadašnjih istraživanja u domenu značaja porodice u procesu prevencije školskog neuspeha, kao moguće pedagoške implikacije izdvajaju se tri vrste uključivanja roditelja u obrazovanje dece i mogući saveti upućeni učenicima i roditeljima u cilju suzbijanja školskog neuspeha. Roditelji se mogu uključiti u obrazovanje svoje dece na sledeće načine: 1) neposrednim radom na školskim zadacima - pružanje neposredne pomoći detetu u rešavanju školskih zadataka; 2) posrednim radom sa detetom izvan okvira školskih zadataka - briga o detetu u slobodno vreme i kontinuirano stvaranje prilika za učenje u vannastavnim i vanškolskim aktivnostima; 3) uspostavljanjem saradnje sa školom - aktivno traženje ili održavanje saradnje sa školom (Bedeniković, 2009). U vezi sa tim, može se govoriti o određenoj vrsti saveta koji su namenjeni učenicima i roditeljima. Tako, učenicima se savetuje da: shvate da od njihovog zalaganja zavisi i njihov školski uspeh; bez ustručavanje potraže pomoć u učenju, ukoliko im je potrebna; stvore posebne veze sa ško- 
lom, na primer, kroz sportske aktivnosti, sekcije, klubove ili druge brojne vannastavne aktivnosti; vode računa o tome da izvršavaju svoje zadatke na vreme; učenju posvete više od 16 sati nedeljno, manje gledaju televiziju, a u skladu sa današnjom digitalnom generacijom, manje provode vremena na društvenim mrežama i surfujući Internetom. Kako bi pomogli svojoj deci u izvršavanju školskih obaveza, roditeljima se upućuju sledeći saveti: da redovno pregledaju domaće zadatke svoje dece; da im kroz razgovor ukažu na značaj obrazovanja i akademski uspeh za njihovu budućnost; da učestvuju i/ili organizuju putovanja u obrazovne svrhe; da nadziru decu tokom vremena koje posvećuju učenju; da pokazuju interesovanje i da se uključuju u školski život deteta (Bethani et al., 1995, prema: Malinić, 2007).

Ključ za uspešno rešenje problema nalazi se u uspostavljanju partnerstva između porodice i škole. Postavlja se pitanje čiji je zadatak da inicira uspostavljanje partnerstva, ali i kako se vrši raspodela zadataka među partnerima? Zadatak roditelja se ogleda u kontinutiranom praćenju svih školskih obaveza deteta, ali i u prihvatanju saradnje sa školom koju deca pohađaju, kako bi dobili pravovremene i relevantne informacije o njihovom akademskom napretku, aktivnostima učenja i mogućim problemima. Na školskom sistemu je da inicira saradnju, te da pruži pomoć roditeljima u vidu savetovanja i podsticanja kako bi uspeli da zahteve, očekivanja i aspiracije usklade sa mogućnostima učenika. Takođe, podršku treba pružiti informisanjem roditelja na koje načine mogu da pruže deci adekvatne podsticaje, obezbede odgovarajuću sredinu za učenje i razvoj, kako bi pratili njihov rad i pravovremeno reagovali ukoliko se poteškoće u učenju pojave. Pored porodice i škole, u procesu rešavanja ovog kompleksnog problema treba da učestvuju i predstavnici društvene zajednice, jer školski neuspeh nije samo problem bitan za pojedinca, već i za društvo u celini, te otkrivanje mogućnosti za razvoj strategija prevencije školskog neuspeha iz ugla ekološke sistemske teorije razvoja, koje bi obuhvatile sve nivoe sistema (mikrosistem, mezosistem, egzosistem i makrosistem), odnosno saradnju porodice, škole i društvene zajednice može biti predmet proučavanja budućih istraživanja.

\title{
Lana Tomčić,
}

University of Novi Sad, Philosophy faculty

\section{PREVENTION OF SCHOOL FAILURE: FAMILY IMPORTANCE}

\begin{abstract}
In pedagogical literature, school failure is most frequently defined as failure to meet the minimum requirements in acquiring knowledge and achieving educational tasks during the teaching process. The family, as the basic social environment in which
\end{abstract}


the child acquires the first experiences, the first models, is recognized as one of the most important factors of student's school failure. The aim of this paper is an overview of family environment factors that affect school failure phenomenon, but also the importance and possibility of establishing a partnership between the family and school in order to prevent school failure. The research aim is realized at the theoretical level, using the method of theoretical analysis. Based on the study of relevant literature, one can conclude that the following factors are recognized as dominant: socioeconomic status, family structure, parenting style of upbringing, their involvement in children's education, expectations and emotional support. Conscious of the fact that the modern way of life places parents in front of various challenges and makes it difficult to fulfil their role, researchers of school failure have questioned the possibilities of establishing a partnership between the family and school in order to overcome school failure, and among other things, two strategies of partnership have been presented: the concept of parental involvement and advisory strategies.

Key words: family, school failure, failure factors, family and school partnerships

\section{Literatura}

Álvarez-Blanco, L. \& R. A. Martínez-González (2016). Cooperación entre las Familias y los Centros Escolares como Medida Preventiva del Fracaso y del Riesgo de Abandono Escolar en Adolescentes. Revista Latinoamericana de Educación Inclusiva, 10(1), 175-192

Babarović, T., Burušić, J. i Šakić, M. (2009). Uspješnost predviđanja obrazovnih postignuća učenika osnovnih škola Republike Hrvatske. Društvena istraživanja, 18(4-5), 673-695.

Baucal, A., Pavlović-Babić, D. (2009). Kvalitet i pravednost obrazovanja u Srbiji: obrazovne šanse siromašnih. Beograd: Ministarstvo prosvete Republike Srbije i Institut za psihologiju.

Baucal, A. (2012) Uticaj socio-ekonomskog statusa učenika na obrazovna postignuća: direktni i indirektni uticaji. Primenjena psihologija, 1, 5-24.

Bedeniković, M. (2010). Uloga majke u školskom uspjehu djeteta. Školski vjesnik, 58(3), 331-344.

Bleuer, J. C. and G. R. Walz (2002). New perspectives on counseling underachievers, ERIC Document Reproduction Service, No. ED 470602.

Burstein, L., Fischer, K. B., \& Miller, M. D. (1980) The multilevel effects of background on science achievement: A cross-national comparison. Sociology of Education, 53(4), 215-225.

Čudina-Obradović, M., Obradović, J. (2006). Psihologija braka i obitelji. Zagreb: Golden marketing - Tehnička knjiga. 
Đorđević, J. (1989). Teškoće u učenju i problemi neuspeha u nastavi. Nastava $i$ vaspitanje, 4, 291-302.

Epstein, J. L. and K. C. Salinas (2004). Partnering with Families and Communities. A well-organized program of family and community partnerships yields many benefits for schools and their students. School as Learning Communities, 61(8), 12-18.

Eret, L. (2012). Odgoj i manipulacija: razmatranje kroz razvojnu teoriju ekoloških sustava. Metodički ogledi, 19(1), 143-161.

Gregurović, M., Kuti, S. (2010). Učinak socioekonomskog statusa na obrazovno postignuće učenika: Primjer PISA istraživanja, Hrvatska 2006. Revija socijalne politike, 17(2), 179-196.

Gutvajn, N., Ševkušić, S. (2013). Kako stručni saradnici doživljavaju školski neuspeh učenika. Zbornik Instituta za pedagoška istraživanja, 45(2), 342-362.

Hamre, B.C., Pianta, R.C. (2005). Can Instructional and Emotional Support in the First-Grade Classroom Make a Difference for Children at Risk of School Failure? Child Development, 76 (5), 949-967.

Janković, J., Prošić-Santovac, D. (2009). Porodica kao činilac školskog (ne)uspeha. U Gajić.O (ur.) Evropske dimenzije promena obrazovnog sistema u Srbiji, Zbornik radova/knjiga 5 (str. 387-398). Novi Sad: Univerzitet u Novom Sadu, Filozofski fakultet.

Klemenović, J. U., Cvijanović, N. (2017). Ispitivanje spontanog uključivanja roditelja u obrazovanje dece na početku školovanja. Godišnjak Filozofskog fakulteta u Novom Sadu, XLII(2), 210-224.

Krstić, K. (2016). Različiti pristupi u proučavanju porodice. Norma, XXI, 2, 361-373.

Lam, G. (2014). A Theoretical Framework of the Relation between Socioeconomic Status and Academic Achievement of Students. Education, 134(3), 326-331.

Lee, J. \& Bowen, N. K. (2006). Parent involvement, cultural capital, and the achievement gap among elementary school children. American Educational Research Journal, 43, 193-218.

Malinić, D. (2007). Kako pomoći neuspešnom učeniku. Zbornik Instituta za pedagoška istraživanja, 39(1), 86-98.

Malinić, D. (2009). Neuspeh u školskoj klupi. Beograd: Institut za pedagoška istraživanja.

Matković, T. (2010). Obrazovanje roditelja, materijalni status i rano napuštanje školovanja u Hrvatskoj: trendovi u proteklom desetljeću. Društvena istraživanja: časopis za opća društvena pitanja, 19(4-5), 643-667.

Milošević, N. (2002). Uticaj saradnje porodice i škole na socijalno ponašanje i školsko postignuće učenika. Zbornik Instituta za pedagoška istraživanja, 34, 193-212.

Musitu, G. \& Cava, M. J. (2001). La familia y la educación. Barcelona: Octaedro. 
Önder, E. (2016). Causes of school failure from teacher and student's perspective. International Journal on New Trends in Education and Their Implications, 7(2), 9-22.

Pahić, T., Miljević-Rađički, R., Vizek-Vidović, V. (2010). Uključenost roditelja u život škole: percepcija roditelja opće populacije i predstavnika roditelja u školskim tijelima. Odgojne znanosti, 12(2), 329-346.

Pavić, Ž., Vukelić, K. (2009). Socijalno podrijetlo i obrazovne nejednakosti: istraživanje na primjeru osječkih studenata i srednjoškolaca. Revija za sociologiju, 40/39(1-2), 53-70.

Pelemiš, D. S., (2017). Vaspitni stil roditelja kao faktor opšteg uspeha učenika. Pedagoška stvarnost, LXIII(1), 27-40.

Polovina, N. (2008). Doprinosti škole građenju partnerstva sa roditeljima. Zbornik Instituta za pedagoška istraživanja, 40(1), 152-171.

Polovina, N. (2009). Obrazovanje roditelja i odnos prema školi njihovih ćerki i sinova. Zbornik Instituta za pedagoška istraživanja, 41(1), 76-99.

Popović, D. (2010). Partnerstvo porodice i škole kao faktor prevencije vršnjačkog nasilja. Pedagoška stvarnost, 1-2, 35-45.

Popović, D., Zuković, S. (2014). Partnerstvo porodice i škole u uslovima tranzicije. Zbornik radova Filozofskog fakulteta, 1, 219-235.

Rečić, M. (2003). Obitelj i školski uspjeh učenika. Đakovo: Pedagoška biblioteka.

Reis, S. M. \& McCoach, D. B. (2000). The underachievement of gifted students: What do we know and where do we go? Gifted Child Quarterly, 44, 152-170.

Santín-González, D. (2006). Familia, escuela y fracaso escolar. En M. T. López (Dir.), La familia en el proceso educativo (pp. 181-222). Madrid: Ed. Cinca.

Slijepčević, S., Zuković, S., Kopunović, R. (2017). Roditeljska očekivanja i školsko postignuće učenika. Zbornik Odseka za pedagogiju, Filozofski fakultet u Novom Sadu, 26, 157-174.

Sremić, I., Rijevac, M. (2010). Povezanost percepcije majčinog i očevog roditeljskog ponašanja i školskog uspjeha kod učenika osnovne škole. Odgojne znanosti, 12(2), 347-360.

Stanojlović, B. (2016). Osnovi pedagoške dijagnostike. Beograd: Učiteljski fakultet.

Sušanj-Gregorović, K. (2017). Roditeljska uključenost u obrazovanje djeteta: stavovi i praksa učitelja. Školski vjesnik, 66(3), 347-376.

Šaranović-Božanović, N. (1984). Uzroci i modeli prevencije školskog neuspeha. Beograd: Institut za pedagoška istraživanja.

Škutor, M. (2014). Partnerstvo škole i obitelji - temelj dječjeg uspjeha. Napredak, 155(3), 209-222.

Trnavac, N. (2010). Pedagogija - udžbenik za nastavnike. Beograd: Naučna KMD.

Tyrone C. Howard \& Rema Reynolds (2008). Examining Parent Involvement in Reversing the Underachievement of African American Students in Middle-Class Schools. Educational Foundations, 79-98. 
Vrkić-Dimić, J., Zuckerman, Z., Blaži-Pestić, M. (2017). Pojedini aspekti uključenosti roditelja u školovanje učenika sa specifičnim teškoćama u učenju i učenika bez teškoća. Napredak, 158(1-2), 49-68.

Zloković, J. (1998). Školski neuspjeh - problem učenika, roditelja i učitelja. Rijeka: Filozofski fakultet, Odsek za pedagogiju.

Zuković, S. (2012). Porodica kao sistem - funkcionalnost i resursi osnaživanja. Novi Sad: Pedagoško društvo Vojvodine.

Zuković, S. (2013). Partnerstvo porodice, škole i zajednice - teorijski i praktični aspekt. Godišnjak Filozofskog fakulteta u Novom Sadu, XXXVIII, 55-68.

Zuković, S. (2017). Savetodavni rad u institucijama vaspitanja i obrazovanja: teorijski i praktični aspekti. Novi Sad: Filozofski fakultet.

Yildirim, U., Eryilmaz, A. (1999). Effects of gender, cognitive development and socioeconomic status on physics achievement. Hacettepe Üniversitesi Eğitim Fakültesi Dergisi, 15, 121-126.

Young, D. J., Fraser, B. J. (1993). Socio-economic and gender effects on science achievement: An Australian perspective. School Effectiveness and School Improvement, 4(4), 265-289. 